CASE STUDY

\title{
Bard High School Early College A Case Study
}

November 21, 2019

Cindy Le

Emily Schwartz

Martin Kurzweil

Elizabeth Davidson Pisacreta

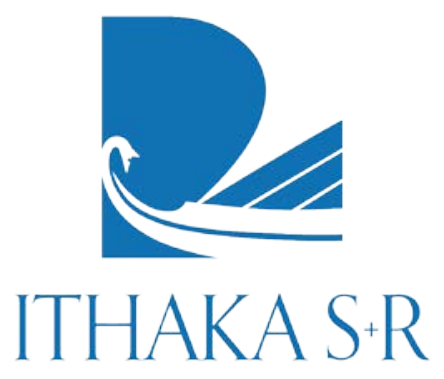




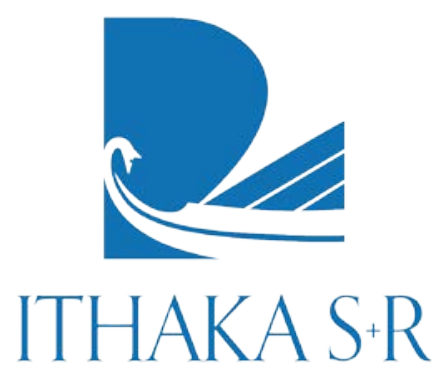

Ithaka $\mathrm{S}+\mathrm{R}$ provides research and

Copyright 2019 ITHAKA. This work is strategic guidance to help the academic and cultural communities serve the public good and navigate economic, demographic, and technological change. Ithaka $\mathrm{S}+\mathrm{R}$ is part of ITHAKA, a not-for-profit organization that works to advance and preserve knowledge and to improve teaching and learning through the use of digital technologies. Artstor, J STOR, and Portico are also part of ITHAKA. licensed under a Creative Commons Attribution-NonCommercial 4.0 International License. To view a copy of the license, please see http://creativecommons.org/licenses/by-nc/4.0/.

ITHAKA is interested in disseminating this brief as widely as possible. Please contact us with any questions about using the report: research@ithaka.org. 


\section{Introduction}

A rigorous liberal arts undergraduate experience has long been the benchmark for higher education in America. Broad-based, with areas of depth, and many opportunities for rich discussion, application, and writing, the liberal arts experience cultivates human potential, prepares students for the start of their career, and readies them for lifelong learning and for adapting to new circumstances. As automation extends throughout our economy, the human skills developed through the liberal arts will only become more important.

Yet, as with many similar benefits, access to the valuable liberal arts experience has historically been limited to relatively few, most of them privileged. While liberal arts colleges opened themselves up in several, dramatic ways in the middle of the twentieth century - to women and people of color, most notably —and many provide significant financial aid to defray costs, today's liberal arts colleges still predominantly serve students who are white, wealthy, and come from college-going families.

Recognizing that talented young people come from every zip code and that they have a responsibility to educate a more diverse group of future leaders, a number of liberal arts colleges are working to broaden access further, many of them in collaboration with one another through the American Talent Initiative. ${ }^{1}$ In some cases, they are doing so not only because it's the right thing to do, but because it's necessary for them to sustain themselves: the declining share of the population who are of traditional college-going age and financially well off means that these institutions need to serve a broader segment of society to survive.

While many of these institutions are focused on how to bring more students of different backgrounds to their campus, Bard College, a liberal arts college whose home campus is in Annandale-on-Hudson, New York, stands out for its focus on bringing the liberal arts to students who have not previously had access where they are. Some examples of Bard's efforts to extend the reach of the liberal arts include its extensive prison education program, its campuses in Kyrgyzstan, Russia, and the West Bank, and its free "microcolleges" in locations such as the Brooklyn Public Library.

The Bard High School Early Colleges (BHSECs), first opened in 2001, are Bard's effort to extend the liberal arts college experience to public high school students who might not

${ }^{1}$ The American Talent Initiative is a national coalition of high-graduation-rate colleges and universities that have committed to a goal to attract, enroll, and graduate an additional 50,000 low- and moderate-income students by 2025 . For more information about the initiative, please visit www.americantalentinitiative.org 
otherwise have access to it. The BHSECs offer public high school students rigorous coursework and exposure to other markers of the liberal arts experience, the opportunity to earn college credit and an associate's degree alongside their high school diploma, and intensive support in applying to and transitioning to a four-year college or university. Through philanthropic support and partnerships with public school districts, Bard is able to offer these opportunities at no cost to enrolled high school students.

An independent evaluation conducted by the research firm Metis Associates provides evidence that the BHSEC model improves access, affordability, and success in higher education for its students. ${ }^{2}$ Compared to similarly situated peers in other district schools, New York City BHSEC students are significantly more likely to graduate from high school. These BHSEC graduates also enroll in and graduate from four-year colleges and universities at rates far higher than their peers: 97 percent of 2012 BHSEC Manhattan and Queens graduates in enrolled in college, compared to 82 percent of their peers. In addition, the researchers found that students and their families see significant financial benefit from transferring the tuition-free college credits they earn at BHSEC towards a four-year degree. Furthermore, 79 percent of BHSEC students finish a bachelor's degree in six years or less. ${ }^{3}$ Nationally, around 60 percent of students who start college earn a degree within eight years. ${ }^{4}$

This case study aims to get under the hood of these impressive results by examining the structural and pedagogical elements of the BHSEC model. Through interviews with administrative staff at Bard, school leaders, faculty, and students, a site visit to BHSEC Queens in New York City, and analyzing available data, this case study explores the model and provides a set of actionable insights for higher education leaders and other stakeholders who are exploring alternative strategies to improve access to the liberal arts experience.

Several key lessons stand out. First, BHSEC's experience shows that early college is a viable and valuable strategy not only for public and community colleges, but also for private, selective colleges. The success of the BHSEC model has shown that a rigorous liberal arts experience can be adapted effectively to an early college program and that selective colleges with a track record of success have a lot to offer in this field. Second, hiring and training quality faculty is critical to success, although doing so may be

\footnotetext{
2 "Equity \& Excellence," Bard High School Early College, http://online.pubhtml5.com/klst/izem/.

${ }^{3}$ Interviews with Bard staff, faculty, and administrators by authors, New York, 2018-19.

4 Todd Sedmak, "60 Percent of All College Students Graduate with a Bachelor's, Associate or Certificate Degree within Eight Years," National Student Clearinghouse, February 12, 2019, https://studentclearinghouse.org/blog/60-percent-of-all-collegestudents-graduate-with-a-bachelors-associate-or-certificate-degree-within-eight-years/.
} 
challenging given the unique demands for teaching early college and the pool of applicants available. For BHSEC, faculty who have experience with both university teaching and K-12 teaching are ideal, although rare, which poses a challenge for school administrators. Another challenging but necessary component of establishing a successful early college is developing and maintaining a positive relationship with the local school district, to ensure that the valuable aspects of the model can thrive within the regulatory and cultural constraints of the district. Finally, there is a tension that must be balanced between the objective of expanding access to a high quality, liberal arts college education to lower-income young people and ensuring that students who enroll in early college are sufficiently prepared to thrive in that environment. BHSEC, which employs a rigorous multi-step process for admissions, believes that it is striking the right balance between preparation and access, and that rigor itself is a necessary challenge for students. Other institutions pursuing this type of model will need to strike their own balance.

\section{Background on Early College Programs}

Opportunities for early exposure to college experiences have shown promise in improving the prospects for high school students both to graduate high school and attain postsecondary degrees. Dual enrollment, where students are simultaneously enrolled in both high school and college, allows students to take college-level courses at their high school, at a college campus, or even online. ${ }^{5}$ There are many types of dual enrollment, such as simple dual enrollment, where students can earn either high school or college credit, but not both, for a single course. In dual credit programs, students earn both high school and college credit for the same course.

Early college high schools, such as the BHSECs, combine both simple and dual credit courses to provide high school and college coursework through one comprehensive program for students. ${ }^{6}$ Early colleges tend to have a set sequence of courses and provide students social and academic support to help them adjust to a rigorous college curriculum. Early college programs generally grant students an associate's degree upon completion, or two years' worth of college credit. Because these credits are earned during high school, there is usually little or no cost for students and their families. Early college

\footnotetext{
${ }^{5} \mathrm{~A}$ study based on Texas data found that dual enrollment students, as compared to AP exam students, are more likely to be rural, have lower incomes, have lower SAT scores, have lower GPAs, and more likely to be African American or Hispanic. Colorado Department of Higher Education, "Policy Brief: Concurrent and Dual Enrollment," https://highered.colorado.gov/Academics/concurrent/Dual-Enrollment-Policy-Brief.pdf.
}

6 "Dual Enrollment: Models, Practices, and Trends." Hanover Research, July 2014, https://www.hanoverresearch.com/wpcontent/uploads/2017/08/Dual-Enrollment-Models-Practices-and-Trends.pdf. 
opportunities operate with the assumption that early exposure to a college curriculum will engage students and motivate them to earn college credit and continue their postsecondary education. Bard believes that early college goes beyond that aim, addressing under-engagement in high school, under-preparation for higher education, under-matching, and the inaccessibility of expensive and selective degree programs.

Dual enrollment is growing in popularity, with the number of students increasing by 80 percent from 2002 to 2010 nationally, according to the National Center for Education Statistics. ${ }^{7}$ Despite this rapid increase in participation, there is very little research on the extent to which students' dual enrollment credit is actually accepted at the institutions they ultimately attend. ${ }^{8}$ One study of University of Connecticut's Early College Experience program found that students lost 13 percent of their credits on average when transferring. Another study of early college high schools in Texas found that of credits that transfer, only 73 percent of the credits applied towards the student's major. Credit transfer rates are generally higher for universities and high schools that have partnerships. Despite this, only half of states have agreements that require public institutions to accept dual enrollment credits. ${ }^{9}$ The issue of quality verification of earned credits plays a large role in the reluctance of institutions to readily accept dual enrollment credit. However, it is important to note that transferability of credit is not just an issue for early college programs. For students transferring from community colleges to four-year institutions, only 58 percent of students have more than 90 percent of their credits transfer. ${ }^{10}$

Early college students are more likely to enroll in college than their peers are, with this effect being stronger for two-year college enrollment than four-year college enrollment. ${ }^{11}$ Early college students are also more likely to earn a college degree than their peers, with similar effects across demographic characteristics. ${ }^{12}$ Data from the National Student

\footnotetext{
7 "Dual Enrollment Programs and Courses for High School Students at Postsecondary Institutions: 2010-11," National Center for Education Statistics, https://nces.ed.gov/pubs2013/2013002/tables/table 01.asp.

${ }^{8}$ Catherine Gewertz, "Are Dual-Enrollment Programs Overpromising?" Education Week, February 20, 2019, https://www.edweek.org/ew/articles/2016/09/07/are-dual-enrollment-programs-overpromising.html.

${ }^{9}$ lbid.

${ }^{10}$ Grace Chen, "Avoid Losing Community College Credits When Transferring to a University," Community College Review, April 16, 2014, https://www.communitycollegereview.com/blog/avoid-losing-community-college-credits-when-transferring-to-a-university.

${ }^{11}$ Andrea Berger, Lori Turk-Bicakci, Michael Grant, Joel Knudson, and Gur Hoshen, "Early College, Continued Success: Early College High School Initiative Impact Study," American Institutes for Research, January 2014, https://www.air.org/sites/default/files/downloads/report/AIR ECHSI Impact Study Report- NSC Update 01-14-14.pdf.

12 Ibid.
} 
Clearinghouse Research Center show that from 2010 to 2016, 88 percent of students who participated in dual enrollment during high school had matriculated at a higher education institution by the time they were 20 . In addition, 41 percent of those dual enrollment students went on to a four-year college. ${ }^{13}$

Studies have shown that these benefits are not simply a result of which students choose to pursue early college. A study from Columbia University's Teachers College, based on dual enrollment programs in California, found that dual enrollment increased high school graduation rates, increased the likelihood of attending a four-year college, decreased the need to take remedial courses in college, and increased the accumulation of college credits for low-income students. ${ }^{14}$ A specific randomized trial found that advanced algebra dual enrollment courses led to better outcomes in math, reducing the need for remedial math classes and increasing enrollment in higher-level math courses. Additionally, students in these advanced algebra dual enrollment classes were more likely to matriculate at a four-year university, as opposed to a two-year college. ${ }^{15}$ Once in a college or university, dual enrollment students also perform similarly to or better than traditional students in terms of grades. ${ }^{16}$ According to a literature review, most dual enrollment studies show that students who participated in dual enrollment generally perform better in college than those who do not participate. ${ }^{17}$ The literature also indicates that dual enrollment increases the likelihood of degree attainment. In Texas specifically, students who participated in dual enrollment were 1.77 times more likely to obtain a bachelor's degree within six years compared to students who did not. Although fewer studies examine the effect of dual enrollment on time to degree, the existing studies suggest that dual enrollment does decrease the time needed to obtain a four-year degree. These findings hold regardless of differences in demographics, such as race, class, or gender.

\footnotetext{
13 John Fink, Davis Jenkins, and Takeshi Yanagiura, "What Happens to Students Who Take Community College 'Dual Enrollment' Courses in High School?" Community College Research Center, September 2017, http://ccrc.tc.columbia.edu/media/k2/attachments/what-happens-community-college-dual-enrollment-students.pdf.

14 Hanover Research, "Dual Enrollment: Models, Practices, and Trends," July 2014, https://www.hanoverresearch.com/wpcontent/uploads/2017/08/Dual-Enrollment-Models-Practices-and-Trends.pdf.

${ }^{15}$ Steven W. Hemelt, Nathaniel Schwartz, and Susan M. Dynarski, Dual-Credit Courses and the Road to College: Experimental Evidence from Tennessee (July 2019). IZA Discussion Paper No. 12481. Available at SSRN: https://ssrn.com/abstract=3427620

16 Jill D. Crouse, and Jeff Allen, "College Course Grades for Dual Enrollment Students," Community College Journal of Research and Practice 38, no. 6 (2014): 494-511.

${ }^{17}$ Brian P An, and Jason L. Taylor, "A Review of Empirical Studies on Dual Enrollment: Assessing Educational Outcomes," in Higher Education: Handbook of Theory and Research, pp. 99-151. Springer, Cham, 2019.
} 


\section{Bard High School Early College}

The Bard High School Early College model strives to bring a rigorous, liberal arts college education to younger students who are ready for such an experience, specifically to high school students who would not ordinarily have the opportunity. Because the BHSECs are run in partnership with public school districts, which provide per-pupil high school funding to offset core operating costs, finances are not a barrier for low-income students, meaning the model can bring college to any student, regardless of family background. Bard is the only example of a liberal arts institution - as opposed to a community college-providing early college programs. It has evidence of success for students and has achieved some scale through replication.

This section takes a deep dive into the BHSEC example to unpack the origins of the model and the components that have helped make it successful and to provide some insight into the process of creating and maintaining an early college from the perspective of a liberal arts college. While the features, strategies, and considerations are unique to the context of Bard College and each of its BHSEC sites, there are also generalizable lessons in the choices and experiences of BHSEC as it has navigated its way.

\section{The Bard Network}

Bard College is deeply committed to expanding access to a liberal arts education beyond the confines of its residential campus. The BHSECs are one way Bard fulfills this commitment-it is important to contextualize that effort within the broader network that Bard has established to expand opportunity in the liberal arts.

Bard has established satellite campuses in several countries that do not have a tradition of liberal arts education, including Kyrgyzstan, Hungary, Russia, and Palestine. The Bard Prison Initiative (BPI), which started in 2001, brings a liberal arts education to incarcerated individuals. BPI enrolls over 300 students, and upon graduation, these students all receive degrees from Bard College, with the same access to an extensive support network as alumni. The students enroll full-time and participate in the same curriculum as Bard's residential students, and 97.5 percent of students who graduate from BPI never return to prison. To date, 14 colleges have joined BPI in these efforts, expanding the reach of the program.

Recently, Bard has launched an additional endeavor, the Bard Microcolleges, to bring a liberal arts education to communities where students may have more difficulty accessing higher education. Each of Bard's microcolleges was created in partnership with a community-based organization whose mission aligns with Bard's philosophy. These 
partners provide credibility, familiarity with the local environment, and physical space for students to learn, while Bard provides the curriculum, faculty, academic advising, and tutoring. The programs focus on career development, with the idea that students will graduate with skills that will help them find employment. Students who are unable to receive full federal and state aid have their tuition and books covered by full scholarships from Bard.

In addition, BHSEC is not Bard's only early college offering. Bard also operates Early College Centers, which allow public high school students to take undergraduate college courses tuition-free. These students enroll part-time, unlike BHSEC students, and still attend their local high school. Afterwards, they earn a year of transferable credits along with their high school diploma.

\section{Origins and Expansion of the BHSEC Model}

The first early college established in the United States, Simon's Rock, began in 1966 and became part of the Bard College network in 1979, spearheading Bard College's work in early college. The motivation for Simon's Rock was the belief that young people were prepared for a rigorous college curriculum at an earlier age. However, not all students who may have benefited from the private early college experience could afford it, so Bard brought this model to a public setting to reach a wider range of students, utilizing a large part of the early college model from Simon's Rock. The New York City Department of Education approached Bard with interest, and in 2001, one of the first public early college high schools in the country opened. ${ }^{18}$ The Bill and Melinda Gates Foundation, which has invested more than 4o million dollars in early college programs, provided some of the funding. Bard College president Leon Botstein is deeply committed to the early college movement, and having been in office since 1975, has provided continuity in Bard's early college involvement. Botstein's book, J efferson's Children, published before the first BHSEC opened, argues for a shorter high school period, with students beginning college at age 16. Botstein believes that teenagers are as academically capable as adults and even suggests eliminating middle school entirely, allowing students to proceed through high school and to college at a faster pace.

The success of the BHSEC Manhattan campus has inspired the steady expansion of the BHSEC model. In response to the high demand from New York City public school students for the BHSEC Manhattan campus, Bard expanded to a second location in the city in 2008, this time in Queens. This was just the beginning of replicating the BHSEC model; over time, Bard gradually expanded to what is now a network of seven campuses,

${ }^{18}$ Bard High School Early College, https://bhsec.bard.edu/about/our-historyl. 
including Newark, NewJ ersey (founded 2011), Cleveland, Ohio (East and West campuses, founded 2017 and 2014, respectively), Baltimore, Maryland (founded 2015), and most recently, Washington D.C. (founded 2019).

In each case, Bard considered several factors in making the decision to develop a new campus:

- Whether the new campus will operate with partners (school district, education organization, etc.) who enable Bard to manage a campus with integrity and autonomy;

- Whether the new campus is poised for longevity, with a viable long-term fiscal plan, sustainable public funding with a contribution to cover Bard's direct and indirect costs, strategic significance to the early college movement and/ or Bard College, viable plans for the operation to appropriately support Bard College, and a Memorandum of Understanding that looks beyond the campus's start-up years;

- Whether the new campus is positioned to serve motivated, intellectually curious students from diverse backgrounds, particularly those underrepresented in college degree completion; and

- Whether the new campus provides a strategically valuable opportunity to raise the visibility and public position of the early college model and of Bard's network.

Typically, initial interest in launching a new site comes from the district itself, which also serves as a useful indicator that district staff will be supportive of the working relationship. For example, conversations about the Newark site began with an invitation from then-mayor Cory Booker. Ideally, the district may also already have funders already interested in supporting the start-up of a new site. Although there are no immediate plans to open additional campuses, BHSEC administrators are always considering other opportunities to expand.

\section{BHSEC Students and Faculty}

As of fall 2017, the BHSECs enrolled almost 2,500 students. The largest student population is at BHSEC Queens, with 623 students. Cleveland East had the smallest population, with 58 students joining the initial cohort in 2017. Racial demographics of students vary by campus, often reflecting the demographics of the host city. For example, 62 percent of BHSEC Newark, 80 percent of BHSEC Baltimore students, and 100 percent of Cleveland East students are black. Across all campuses, 15 percent of students 
are Asian, 40 percent black, 17 percent Hispanic, and 26 percent white. ${ }^{19}$ Across all campuses, girls outnumber boys 63 percent to 37 percent, with similar percentages for individual campuses. Forty percent of students at BHSEC are first-generation, and an estimated 68 percent are eligible for federal Pell grants. ${ }^{20}$

The BHSECs have a total teaching faculty of 227, with Manhattan and Queens employing 58 and 57 faculty, respectively, and Cleveland East employing six. ${ }^{21}$ Non-teaching staff can range from seven to 20, with traditional high school roles such as guidance counselor and principal, but also college-specific roles such as director of college transfer and dean of academic affairs. ${ }^{22}$ BHSEC faculty are highly qualified, with over two-thirds of faculty holding a terminal degree and many having prior college teaching experience. ${ }^{23}$ Faculty are less diverse than students: 10 percent of faculty members are Asian, 11 percent black, five percent Hispanic, and 52 percent white. ${ }^{24}$ These are similar to national levels, where 11 percent of postsecondary faculty members are Asian, six percent are black, and five percent are Hispanic. ${ }^{25}$

\section{BHSEC Curriculum and Pedagogy}

The first two years at BHSEC are considered high school years, while the final two years are considered college years. They are described accordingly - after ninth and tenth grade, students transition to Year 1 (as in, the first year of their college program) and then Year 2. The curriculum is designed for students to complete their high school requirements as well as an associate's degree by the end of Year 2 (their fourth year in the school).

In ninth and tenth grade, students take a typical, advanced high school curriculum, although there is a more intense focus on writing and critical thinking than in many other high schools, to ensure that students are prepared to take their college courses by Year 1. The emphasis on writing and critical thinking begins with the Writing and

\footnotetext{
${ }^{19}$ Bard High School Early College, "Class of 2017 Graduation Report."

$20 \mathrm{lbid}$.

21 Ibid.

22 Bard High School Early College, https://bhsec.bard.edu/queens/our-people/staff/.

${ }^{23}$ Bard High School Early College, "BHSEC Fact Sheet"

${ }^{24}$ Bard High School Early College, "Class of 2017 Graduation Report."

25 "Digest of Education Statistics," National Center for Education Statistics, https://nces.ed.gov/programs/digest/2018menu tables.asp.
} 
Thinking Workshop, which students participate in starting in ninth grade. The annual, intensive workshop focusing on critical reading and writing is held at the beginning of each school year and is based on Bard College's Writing and Thinking program, which exists in Annandale-on-Hudson and Bard campuses across the globe. BHSEC classes incorporate the teaching methods introduced in the Writing and Thinking Workshop, utilizing methods such as focused free-writing, process writing, and small group critique. Classes are often organized to promote thinking and discussion, with students seated in a circle or square to facilitate discussion. Teachers tend not to lecture, instead eliciting discussion with a question or prompt to encourage students to talk with each other. ${ }^{26}$

Once students reach Year 1, they begin college-level courses, including a First Year Seminar that is a hallmark of the curriculum at Bard College and all campuses in the network. Students continue taking seminar courses through Year 2. In the second year of the seminar, all students are required to write a thesis. The Year 1 and Year 2 seminar sequence teaches BHSEC students essential skills for college, such as critical thinking, close reading, academic research, and debate, with each subsequent course building on the last. The classes themselves focus on writing, active discussion, and presentations. For example, a group of students might be asked to read a text and prepare a lesson and direct discussion for the other students. The seminars are interdisciplinary, covering topics including history, literature, and philosophy, with classes taught by faculty from different departments. Seminar classes have a maximum of 25 students per class, and professors for these courses are all trained on early college pedagogy. ${ }^{27}$

The BHSECs provide elective courses across the disciplines, as well as tutorial classes, which involve more in-depth coursework under the supervision of a faculty member, with an individual student or a small group of one to three students. The topics for these in-depth courses might follow the syllabus for a class that is not currently being offered, but can also be on a unique topic, with the curricular elements designed by the student and supervising faculty member.

Each year, faculty members attend workshops to learn techniques specific to helping younger college students with writing and discussing texts. Faculty at both Bard College and at the BHSECs meet at least once a year to discuss curriculum and reading texts. Outside of this main sequence, each campus may vary slightly to conform with city requirements, but the actual course specifics are quite consistent. In fact, to build

${ }^{26}$ Bard High School Early College Folio, "Teaching Critical Thinking."

${ }_{27}$ Bard High School Early College, https://bhsec.bard.edu/wp-content/uploads/2019/05/Bard-Sequence-Overview.pdf. 
coherence, the leaders of the branch campuses have monthly conference calls and semiannual summits.

BHSEC programming expands beyond the classroom: BHSEC Queens will regularly invite guest speakers to the campus through their "Dean's Hour," introducing students to a wide range of perspectives, an opportunity many students would not otherwise have until college. The schools also offer a summer bridge program for incoming ninth grade students, similar to summer orientation for college freshmen. Once students enter Year 1 of college coursework, they take part in a matriculation, just as a college student would. There is also a commencement ceremony where students receive their Bard College associate's degrees. For support, students are part of a weekly advisory group focused on socio-emotional skills development. BHSEC students also have the opportunity to visit Bard College's campus for events such as academic conferences, debate tournaments, and Model UN events.

\section{Relationships with Public School Districts}

The launch of a BHSEC campus requires a partnership with the public school district, ideally one that is already willing to rethink existing structures and has strong relationships with the philanthropic community. Other key factors for a successful BHSEC campus launch are a sufficiently large pool of prospective students, a good chance of recruiting high quality faculty, and a regulatory climate that is not prohibitive. The presence of these factors are not on their own right sufficient-Bard and the school district must also come to a consensus about teacher certification, curricular and testing requirements, and facilities before a BHSEC can open.

For example, BHSEC administrators feel strongly about retaining the autonomy to hire staff and administrators. To implement its unique curriculum, Bard requires flexibility and control, but it also must meet state requirements. An added challenge in maintaining a strong district relationship is the high rate of turnover in districts. If a superintendent leaves, it is difficult to build relationships to make sure the partnership can continue. However, BHSEC administrators have found that at the end of the day, districts care about diversity and cultivating talent in the same way that Bard does.

Addressing the nuances of a funding arrangement with a school district and other partners is also a key component of the early stages of new campus planning and integral for establishing a stable district relationship. The financial model for a BHESC is difficult to compare from one district to another-some districts cover all costs, while others are not able to cover busing and facilities. For example, BHSEC Queens and Manhattan each require about $\$ 2$ million per year in philanthropic support above the district- 
provided funds to operate. ${ }^{28}$ This discrepancy in funding is a result of initial negotiations with the NYC DOE in 2001, where budget projections were for a model with no precedent. With a better understanding of the real costs of operating a BHSEC, it has been possible to negotiate sustainable public funding for more recently established partnerships. For Bard's schools in Cleveland, Baltimore, and Washington D.C., public per-pupil funding covers the operating costs of the schools.

\section{Admissions Selectivity and Diversity}

All BHSECS receive more applicants than they have spots available, and so each has established a process to select among applicants. While the admissions processes varyand some campuses are still honing their processes to meet their targets for enrollmentin each case, they are designed to achieve multiple goals similar to those in other college admissions contexts: mission focused goals such as increasing access for underserved student populations; educational goals such as ensuring that students are able to benefit from the experience and contribute to the academic community; and practical goals such as ensuring that revenue from enrollment meets budget expectations.

Core components of the admissions process at all BHSEC campuses are a writing assessment and interview, while some campuses also review middle school records or conduct a math assessment. According to BHSEC's admissions documents, BHSEC is looking for personal qualities that would help a student thrive in the early college program, but at the same time aims to be inclusive of those who may not have had prior access to quality education. ${ }^{29}$ The BHSECs aim to identify these students through personal interviews instead of the high-stakes standardized tests used by many other selective public high schools, which have been shown to disadvantage low-income and minority students. ${ }^{30}$ In short, as Bard's Vice President for BHSECs often says, the BHSECs aim to evaluate applicants based on "the quality of their thinking, not the quality of their preparation."

Many of the differences in admissions across BHSECs are due to local school district policies and contexts. The application process for the New York campuses is extremely competitive. For example, in a given year the BHSEC campuses in New York City receive up to 7,000 applications for approximately 300 spots. ${ }^{31}$ All applicants take a writing and

28 Interviews with Bard staff, faculty, and administrators by authors, New York, 2018-19.

${ }^{29}$ Bard High School Early College Folio, "Outreach and Admissions."

${ }^{30}$ Bard High School Early College Folio, "Outreach and Admissions."

31 Interviews with Bard staff, faculty, and administrators by authors, New York, 2018-19. 
math assessment, and a large subset of those who take the assessments are invited for an interview. ${ }^{32}$ In the admissions cycle for the 2018-2019 school year, a BHSEC Queens faculty committee interviewed more than 2,200 students. ${ }^{33}$ Of these students, approximately 1,000 were placed on a ranked list for acceptance, all of whom school administrators say would be welcomed and successful at the school. The applicants also rank BHSEC among their high school choices and New York's school matching process determines which of the ranked students fill the spots.

In the 2018-19 academic year, 40 percent of students at BHSEC Manhattan and 42 percent of students at BHSEC Queens received free or reduced-price lunch, ${ }^{34}$ compared to 72 percent of New York City public school students. ${ }^{35}$ To make progress on this gap, the BHSEC Queens “Diversity in Admissions” pilot was established in 2017, where the New York City Department of Education and Bard formalized an agreement to launch a new admissions structure that sets aside 63 percent of seats for incoming students who qualify for free or reduced-price lunch. ${ }^{36}$ An important point of comparison is selective liberal arts colleges, and along that dimension, the BHSECs are far more socioeconomically diverse than the norm. Across all the BHSECs, an estimated 68 percent of students are Pell-eligible, compared to 22 percent of residential students at Bard College or 18 percent, on average, at selective private colleges and universities. ${ }^{37}$

Other BHSEC campuses, by contrast, are very popular, but face some challenges in optimizing their enrollments. For example, BHSEC Newark had a goal of enrolling 150 students in the most recent year, but ultimately, only enrolled 130 students. The school received 950 applications, but many did not meet admissions criteria. ${ }^{38}$ Furthermore, the Newark district's complicated matching process and strict deadlines may exclude some qualified applicants, despite spots remaining available. BHSEC Newark staff report receiving numerous phone calls from families who are interested in having their students enroll but missed a deadline.

\footnotetext{
32 Interviews with Bard staff, faculty, and administrators by authors, New York, 2018-19.

${ }^{33}$ Interviews with Bard staff, faculty, and administrators by authors, New York, 2018-19.

${ }^{34}$ Bard High School Early College, "BHSEC Fact Sheet"

${ }^{35}$ New York State Education Department, "KWIC Indicator Narrative," https://www.nyskwic.org/get data/indicator narrative details.cfm?numlndicatorlD=31.

${ }^{36}$ New York City Department of Education, "Diversity in Admissions," https://www.schools.nyc.gov/enrollment/enrollmenthelp/meeting-student-needs/diversity-in-admissions.

37 Using IPEDS data, this analysis looks at Pell enrollment at the 242 private, not-for-profit institutions with graduation rates consistently above 70 percent.

38 Interviews with Bard staff, faculty, and administrators by authors, New York, 2018-19.
} 
At BHSEC Baltimore, the admissions process was established in direct response to the existing landscape of high schools in the city. The city has other selective high schools that admit students based on their middle school grades and standardized test scores, so the district wanted BHSEC to take a different approach. As a result, the admissions process includes only qualitative components: a writing assessment and interview. The campus recruits for 125 incoming freshmen each year, but does tend to over-accept to guard against summer attrition and the pull of highly qualified candidates to other city high schools.

\section{Navigating the Transition from High School to College}

Transitioning from a high school context to a college context can be challenging for many students, especially those from a lower-income or first-generation background. As early colleges, BHSECs help students make that transition earlier in their academic careers and through a more gradual, cohesive, and scaffolded process. The BHSEC model aims to integrate the culture of higher education into all aspects of the school. For freshmen and sophomores, it is helpful to have role models in the older students who are referred to as "first-years" and "second-years" within BHSECs. This vocabulary switch is emblematic of the philosophy of BHSECs: in their final two year, students are truly seen as college students, and are, in fact, formally enrolled in a branch campus of Bard College. The younger students, as a result, can ease into their college years with the older students serving as models. The language of higher education is everywhere, with references to the dean, office hours, the registrar, and bursar-vocabulary many students only encounter when they have left high school. In one interview, a faculty member emphasized the importance of not only teaching students content, but also teaching how to use available resources and independently get access to materials. Students organize academic conferences and jointly lead civically engaged initiatives.

BHSEC campuses function as sites of one larger academic community; for example, faculty are members of academic departments with colleagues across the early college network. There is a chair for each academic program, who coordinates and encourages faculty collaboration, support for research, and discussion of pedagogy. There is a dean of studies who helps lead the Bard Early Colleges, with a focus on academic structures that promote curricular innovation, connection between sites, and a high bar for college quality.

As is often the case in a high school setting, college counselors also help BHSEC students navigate the transition to the next destination. BHSEC will help with typical tasks such as applying to college, making a list of schools, writing essays, test preparation, interviewing, and college fairs, as well as one-on-one meetings with students. BHSEC staff are also available for additional assistance for families who may not be familiar with 
the higher education landscape, evaluating financial aid award letters and providing financial literacy workshops.

One key distinction for BHSEC students embarking on the college search is that they already have college credit, and often an associate's degree, in their pockets. The college search process is framed as "college transfer," which is exactly what it is. This poses unique challenges, however, particularly when it comes to credit transfer. BHSEC staff shared that some colleges are wary of accepting these credits. For students who aspire to enter bachelor degree programs as freshmen, this may not be problematic, and BHSEC administrators do not feel as though credit transfer is a defining goal of this work, instead emphasizing the liberal arts experience and its academic and developmental benefits for the students. However, many students cite the transferability of credit as one of the main benefits of the BHSEC experience, and do hope that it will enable them to finish a bachelor's degree program on an accelerated timeline and at a lower cost. For these students, the acceptance of transfer credit may seem crucial. A BHSEC Queens administrator estimates that about 75 percent of BHSEC Queens students transfer any credits, and about 50 to 60 percent of students transfer a year or more worth of creditsa high number relative to many other dual enrollment programs. ${ }^{39} \mathrm{~A}$ recent survey of alumni found that 85 percent of respondents transferred some credits, including 55 percent who transferred more than a year of college credits. Despite this, students who do want to transfer these credits tend to gravitate toward the schools that have shown friendliness toward BHSEC students and the credits they bring with them.

One of those schools is Bard College itself. Bard was the second most popular destination for alumni from BHSEC Manhattan between 2012 and 2013, after CUNY Hunter College. ${ }^{40}$ Bard accepts all credits earned at BHSECs, and therefore students can complete a bachelor's degree within four to six semesters. BHSEC transfers to Bard receive other benefits, such as the option to apply for either fall or spring admission, advanced notice of admission, and guaranteed on-campus housing. ${ }^{41}$ Many BHSEC administrators spent some time at Bard, and BHSEC faculty trainings often occur at the Bard College campus. The connection is also visible in elements of the curriculum, such as the seminar sequence that is present at both BHSECs and Bard College. ${ }^{42}$

${ }^{39}$ Catherine Gewertz, "Are Dual-Enrollment Programs Overpromising?" Education Week, February 20, 2019, https://www.edweek.org/ew/articles/2016/09/07/are-dual-enrollment-programs-overpromising.html.

40 Bard High School Early College, "BHSEC Alumni Enrollment Report."

${ }^{41}$ Bard High School Early College, "https://www.bard.edu/admission/transfer/."

42 Bard High School Early College Folio, "Seminar." 


\section{Hiring and Developing BHSEC Faculty}

One of the key features of the BHSEC model is hiring teachers who have teaching experience at the college level but can also teach successfully within a K-12 system. While it is helpful for students to have the support of a teacher with college experience, it is often difficult to reconcile the discrepancies between the two academic levels. All BHSEC campuses offer typical high school classes such as Algebra I, Geometry, and Literature of the Americas alongside a First Year Seminar and classes like "Revolutions" and "Antiquity and Science Fiction." Teachers often have to teach both high school and college courses, and have to manage this discrepancy in subject matter. Many departments have weekly meetings to talk about how to improve research and pedagogy, but must also grapple with all the requirements of a high school-parent contact, lesson plans, and regulatory rules with principals.

J oining BHSEC's faculty is a good option for $\mathrm{PhD}$ holders in many ways, especially considering the shortage of full-time postsecondary teaching jobs nationally. Many faculty members enjoy the opportunity to engage in mission-driven teaching with motivated students, in addition to the flexibility of offering courses on subjects of their own choosing. However, finding the right candidates can also be an obstacle. On a logistical level, many professors, understandably, do not want to return to school to earn a master's in teaching, which is often a requirement for K-12 teachers. Although some BHSEC campuses receive a high volume of job applications, it can be difficult to find faculty with the right combination of expertise and a willingness to forego the traditional path of publications and tenure. Across BHSEC campuses, about 59 percent of teachers have a $\mathrm{PhD} .{ }^{43}$ Faculty are often recruited through collegiate channels, although up to one third come from K-12 channels, with many of those holding terminal degrees. ${ }^{44}$

BHSEC Queens typically receives, around 100 applicants -25 of whom are qualified-for a social studies position. For other subjects such as physics, the search can be more difficult, attracting just 20 candidates, only one of whom is qualified. ${ }^{45}$ BHSECs retain between 80 and 90 percent of their teachers annually. ${ }^{46}$ The difficulty in recruitment can come from the perception of early colleges as having widely varied quality and that faculty are high school teachers. These combine to present an obstacle to recruitment: faculty worry that their work at BHSEC will present on a CV like high school teaching

\footnotetext{
${ }^{43}$ Interviews with Bard staff, faculty, and administrators by authors, New York, 2018-19.

${ }^{44}$ Ibid.

$45 \mathrm{lbid}$.

${ }^{46} \mathrm{lbid}$.
} 
and will impede career growth. Often times, qualified potential faculty members simply are not aware of the world of early college. Current faculty members are working to spread the word to former classmates and friends.

When it comes to evaluating teachers, school administrators rate their ability to balance both high school pedagogy and a well-structured classroom with the college aspect of providing freedom and independence to students. Oftentimes, faculty are stronger in one aspect or the other. Principals tend to be evaluated through the K-12 lens- on how well they support faculty, meet general requirements, manage the building, and achieve high graduation rates and test scores. Principals have a large number of responsibilities, and due to the uniqueness of the early college model, not all administrator are prepared to take these on. For example, principals need to navigate a district relationship, especially challenging if district staff are not familiar with early colleges. ${ }^{47}$ The year BHSEC Cleveland opened, only 115 students in the city were involved in some kind of dual enrollment program. This context made establishing an entirely new school model difficult to market and develop. ${ }^{48}$ Despite the difficulties, BHSEC school leaders have relatively long tenures. For example, the leader of BHSEC Queens has been in place for twelve years.

\section{Expansion through Influence}

BHSEC opened a new site in Washington D.C. in 2019, and Bard has opened a school every year for the last six years. While other new BHSECs may be on the horizon, Bard administrators have also shared hopes to provide leadership in pedagogy, partnerships, and public policies that can other liberal arts colleges in establishing their own early colleges.

To that end, dual enrollment programs are sometimes criticized for lack of quality control and rigor, and Bard's leaders believe that the involvement and leadership of academically strong institutions can counter that narrative. At the same time, early college presents those institutions with an opportunity to reach many more young people with a liberal arts experience and to create a more robust pipeline of students into residential liberal arts colleges. By proving the concept of the early college model through their own success, Bard's leaders hope to attract others to join the effort.

${ }^{47}$ Interviews with Bard staff, faculty, and administrators by authors, New York, 2018-19.

${ }^{48} \mathrm{lbid}$. 


\section{Evidence of Success}

Overall, the BHSECs have a graduation rate of 98.4 percent and an associate's attainment rate of 82.4 percent. ${ }^{49}$ The role BHSECs can play in equity is clear when looking at students in Baltimore-system-wide, less than 44 percent of students who graduated in 2015 enrolled in college after they graduated from high school. Comparatively, 92 percent of students in BHSEC Baltimore's first class graduated high school, concurrently with an associate's degree. Furthermore, at BHSEC Baltimore, there is a 96 percent average attendance rate, compared to a 40 percent across other Baltimore city schools. Prior to the opening of BHSEC Baltimore, only 55 students district-wide had access to any form of college in high school program. Today, that number has grown fivefold.

Based on a Metis Associates research study of the BHSEC campuses in Manhattan and Queens, BHSEC students had significantly higher four-year college graduation rates overall than their counterparts who attended either specialized or traditional NYC public schools, and the finding was even stronger for black students and boys. Moreover, BHSEC students were also more likely to enroll in college than the comparison group, and more likely to graduate from college with a bachelor's degree. For example, 77 percent of BHSEC Baltimore's first graduating class enrolled in college within six months of graduating high school, and 85 percent enrolled within 18 months.

Recent analysis of college outcomes for low-income New Yorkers by the Education Trust of New York confirmed the effectiveness of the BHSEC model in preparing low- and middle-income students for success in four-year colleges. The Education Trust analyzed outcomes for college students receiving Tuition Assistance Program (TAP) funding-a form of college financial aid available to families making less than $\$ 80,000$ a year-and found that BHSEC Manhattan and Queens alumni had higher on-time college graduation rates than any other high school in the state of New York. Eighty-nine percent of BHSEC Manhattan alumni and 86 percent of BHSEC Queens alumni who enrolled in college in 2012 and 2013 and received TAP assistance have now successfully completed a four-year degree. 50

A survey of BHSEC Newark alumni indicates that the large majority of respondents have positive impressions of BHSEC, especially the rigor of the coursework and the preparation for college. ${ }^{51}$ Current BHSEC Queens students who were interviewed say

${ }^{49}$ Bard High School Early College, "BHSEC Fact Sheet."

50 "From High School to College Success," The Education Trust, https://newyork.edtrust.org/to-and-throughl.

${ }^{51}$ Metis Associates, "An Examination of Bard High School Early College's Impact on High School and College Success," June 2018. 
that they were drawn by the diverse course offerings and the chance to explore different subject areas as well as to the idea of earning college credits. Students praise the rigorous yet supportive environment and emphasis on a college mindset. Students feel that the BHSEC experience will prepare them well for college, particularly for navigating a world of attending office hours, balancing course work, preparing for new situations and environments, and learning how to utilize free time..$^{52}$ Based on a survey of the Class of 2012, 91 percent of graduating students felt the seminar sequence, in particular, prepared them well for continuing in college. ${ }^{33}$ Based on interviews with students in Cleveland and Baltimore, BHSEC students value the close relationships with their professors, the independence and freedom awarded to students, the high expectations and challenge, and the strong support system.

\section{Takeaways from the BHSEC Experience}

For liberal arts colleges considering an early college as a component of their commitment to equity in education, the BHSECs provide valuable insights into the key criteria for, and possible obstacles to, success. Based on our research, there are at least four highlevel takeaways from the BHSEC experience for others to consider.

\section{Early college is a viable strategy for selective liberal arts colleges}

For reasons of both mission and survival, many liberal arts colleges have set goals to expand access beyond the populations they have historically served. Recognizing the educational value of diverse viewpoints, and having a not-for-profit mission to provide intellectual development and social mobility to young people from all walks of life, these institutions have dedicated resources to recruitment and financial aid for lower-income students, and in some cases have significantly altered the on-campus experience and supports to ensure these students feel welcome on campus. At the same time, most of these institutions are tuition-dependent and are located in areas of the country that are struggling economically and where the number of traditional college-going age students is in rapid decline. To sustain themselves, these colleges must adapt to serve a broader swath of society.

The BHSEC model shows that a liberal arts college can further these aligned aspirational and practical goals through early college. The BHSECs have adapted the core of a liberal arts education to a public, early college setting, ensuring that hundreds of high school

52 Interviews with Bard staff, faculty, and administrators by authors, New York, 2018-19.

${ }^{53}$ Bard High School Early College Folio, "Seminar." 
students each year have access to that rigorous experience at no cost. At the same time, the BHSECs have extended Bard College's enrollment, both directly when students are in Year 1 and 2 at a BHSEC, and indirectly by increasing awareness of Bard College in six cities across the U.S.

\section{Hiring and training effective early college faculty is critical - and challenging}

A cornerstone of the BHSEC model is a high quality and well-trained faculty. However, it can be difficult to find well-qualified candidates who are able to navigate both the higher education and K-12 aspects of an early college high school model, and many of these candidates may not be willing to leave traditional academia. Schools in areas without a robust hiring pool can face even more difficulty. The BHSECs have been successful in hiring faculty and administrators with terminal degrees and teaching experience at the college level. However, some faculty have had difficulty adapting to aspects of the K-12 world, including engaging with parents and working with students with special needs. Bard trains faculty on this unique dichotomy, focusing on how to teach in an early college setting specifically. With proper training in both high school and college pedagogy, workshops, and frequent discussion between faculty members, it seems possible that faculty without terminal degrees could still teach courses that are appropriately rigorous for an early college setting. For districts that struggle with attracting candidates with the ideal qualities, comprehensive training over time could feasibly help fill this gap.

\section{Partnering with a public school district offers incredible value, but requires constant maintenance}

Developing a partnership with the local public school district can bring great value when starting an early college. A partnership with the local district can not only increase interest in the early college model and help attract both students and faculty, but districts can also provide central office support, facilities and other resources, and funding for students. This relationship does need to be maintained over time, and having a positive relationship with school districts can make the day-to-day operations of an early college high school run more smoothly. Questions regarding autonomy, curriculum, hiring, and evaluation should be discussed closely with the district, particularly as the early college program launches. BHSEC administrators feel it is particularly important that Bard maintain the ability to hire and develop curriculum independently of the district and stressed the need to secure sufficient district funding ahead of time. BHSEC administrators also note that maintaining a positive relationship with the district is particularly helpful for hiring new faculty and staff. Having clear communications makes the process simpler, as seen in NewYork BHSECs, where the majority of faculty members are employees of the NYC Department of Education. Bard 
has found that the success of the model has sparked interest in other school districts, who are often the ones that initiate the relationship. School districts can take steps to strengthen these partnerships by developing policies and funding models that keep the needs of early college programs in mind, proactively creating the conditions in which those programs can thrive and grow. One of the biggest next steps for early college work is to create and codify those policy frameworks.

\section{Balancing access and curricular rigor}

The mission of the BHSECs is to broaden access to a liberal arts experience, particularly for students who may otherwise not have the opportunity. At the same time, due to the high level of rigor required for an early college curriculum, it is important for early colleges to ensure that their students are prepared and capable of thriving in such an environment. Increasing selectivity to the point where it is guaranteed that the majority of students will succeed in the environment will drastically decrease the percentage of disadvantaged students who make the cut, as by definition, they have not had the resources and experiences that will help them succeed, despite the fact that they could do well with the right support. On the other hand, a too lenient admissions process would place unprepared students into an environment where they may struggle and be discouraged from pursuing higher education. BHSEC's holistic admissions process, including a writing segment and an in-person interview, aims to find a diverse group of students who have the potential to succeed in the early college environment.

In New York City, where there are far more interested and qualified applicants than spots available, BHSEC has wrestled with how to achieve a balance in admissions. BHSEC Queens, for example, placed approximately 1,000 students of its 3,991 applicants on an acceptance list during the 2018-19 school year, an acceptance rate of roughly 25 percent-compared to the 56 percent acceptance rate at Bard College. New York BHSECs enroll a lower share of low-income students than the overall New York City high-school student population. By contrast, other BHSEC campuses, which are not as oversubscribed, have student populations closer to the demographics of their cities. All of the BHSECs serve a higher share of lower-income students and underrepresented minorities than Bard College and most other residential selective liberal arts colleges.

While the BHSECs continue to refine their admissions processes to further their mission, the fact is, any changes they make will fill only part of the gap. The bigger picture is that there are far more high school students who have shown that they want to pursue a rigorous early college experience and who are prepared to benefit from such an experience than there is capacity to offer that experience. BHSEC has surfaced that latent demand and has managed to make a dent in responding to it; there is room for many more colleges to join in. 


\section{Conclusion}

The Bard High School Early College model is one of the first examples of a selective liberal arts institution involved in the early college movement. With an emphasis on providing rigorous college coursework and training, particularly for lower-income and minority students, the BHSECs have established a curriculum, faculty, and admissions process with proven results for their students in terms of graduation and college enrollment rates. For other institutions, particularly selective colleges, interested in expanding the reach of a rigorous liberal arts experience to students from a range of backgrounds who do not historically have access, early college should be considered as a strategy. The BHSECs have shown what is possible with such an approach. Developing an equitable admissions process leading to qualified and diverse students, hiring faculty prepared to teach across high school and college curriculum, and navigating challenges such as funding and school district regulations are factors with which the BHSECs continue to wrestle. Institutions pursuing an early college high school program should look to the BHSECs for insight on how to address these issues, while keeping in mind the challenges that new contexts, new students, and new sites might present. 


\section{ITHAKA S'R}

\section{Appendix}

We conducted the following interviews with faculty, staff, and administrators at Bard High School Early Colleges between 2018 and 2019. We conducted one in-person interview with a group of students on March 13, 2019.

- Murphy Austin, Data and Evaluation Manager for Bard Early Colleges

- Clara Haskell Botstein, Associate Vice President of Bard Early Colleges

- Frankie Gamber, Principal, BHSEC Baltimore

- Laura Hymson, Dean of Academic Affairs, BHSEC Queens

- Veronica Osorio, Director of Admissions, BHSEC Newark

- Suneeta Sundarsen Paroly, Science Faculty, BHSEC Queens

- Olga Ramos, Director of Admissions, BHSEC Queens

- Valeri Thomson, Principal, BHSEC Queens

- Stephen Tremaine, Vice President of Bard Early Colleges

- J ohn Weinstein, Dean of Bard Early Colleges

- Dumaine Williams, Principal, BHSEC Cleveland

- Lenni Yesner, Director of College Transfer Office, BHSEC Queens

- One group of five current BHSEC Queens students 